\title{
HERITAGE BUILDINGS AS A CONTRIBUTION TO THE CONTEMPORARY CITY: THE RELOCATION OF BRAGA'S DISTRICT ARCHIVE
}

\author{
João Pedro SILVA ${ }^{1,}$, Paulo MENDONÇA ${ }^{2}$, Paulo J. RAMÍSIO ${ }^{3}$ \\ ${ }^{1}$ School of Architecture, University of Minho, Campus de Azurém, 4800 - 058, Guimarães, Portugal \\ ${ }^{2}$ Lab2PT Research Center, School of Architecture, University of Minho, Campus de Azurém, 4800 - 058, \\ Guimarães, Portugal \\ ${ }^{3}$ Civil Engineering Department, School of Engineering, University of Minho, Campus de Azurém, 4800 - 058, \\ Guimarães, Portugal
}

Received 30 May 2017; accepted 21 May 2019

\begin{abstract}
This paper reflects on the ability to adapt buildings with relevant heritage and historical value to different uses and functions. A case study is presented: The relocation of Bragas District Archive from the former Archbishop's Palace in Largo do Paço, a building dating back to the XIVth century confined within the Historical Center's buffer zone, into a modernist building located in Abade Loureira street, North of the original complex and outside the medieval walled city.
\end{abstract}

The methodological approach and the processes associated with the intervention are presented according to the analysis of the proposed program, rather than by the formal and symbolic features of the building itself.

Extensive in-situ surveys took place at the two buildings, comparing both the present and the proposed solution. Based on this analysis, the Program's adequacy is discussed, displaying the advantages and disadvantages of this change and how it may affect the mission of the District Archive.

Keywords: program adequacy, architecture of public buildings, archive, heritage buildings, built environment, architectural conservation.

\section{Introduction}

“(...) The desire of endorsing all times, all eras, forms and styles within a single place, the concept of turning all times into a single place, and yet a place that is outside time, inaccessible to the wear and tear of the years, according to a plan of almost perpetual and unlimited accumulation within an irreversible place."

Michel Foucault (1988). Of other spaces: Utopias and Heterotopias, 1967.

The processes involved in either archiving and/or interventions in objects with architectural or historical value are often quite similar, especially since both deal with a shapeless and transversal matter, that is, memory, its preservation and communication.

Monument, the object that invokes memory, has, in all societies, a fundamental role, to maintain and preserve the identity of a community. The 1987 Washington Charter
(Rodwell, 2003) recognizes its significance, extending the analysis towards the definition of "principles, objectives and methods necessary for the conservation of historic towns and urban areas. It also seeks to promote the harmony of both private and community life in these areas, along with encouraging the preservation of those very same cultural properties, that however modest in scale, constitute the memory of mankind."

Buildings, monuments and sites with historical density, present in our cities are actually, archives of the collective but, they need continuous interpretation and, if required, rewritten to abandon the dome of, the useless monument, of a pure object of contemplative aesthetic experience and announced decay. They should absorb and grasp, when possible and necessary, new programs, as a resource of re-usage, revitalization, preservation of the construction and society, as a definition of sustainability that can be felt. If the foundation supporting the recovery of the ancient architecture resides in the romantic aesthetics of its ruins,

*Corresponding author. E-mail: joaopereirasilva88@gmail.com 
a coeval appreciation of the architecture should be based on this assumption of sustainability, which contributes constructively to an effective improvement of the urban environment in which it relies.

Based on the principles mentioned above, the regeneration of historical buildings depends largely on the correct concern and consideration of their use and the associated program, not only to allow that the planned activities are conducted without interfering and harming its functionality, but also to adjust and adapt it in a conscious manner. Therefore, when these issues are balanced, the pre-existing building and the new use or re-use, leave a valuable contribution, with particular significance, for the redesigning of the contemporary city and likewise for a more complete, complex, and qualified urban ambience (Portas, 2005; Medina, 2011; Varum et al., 2011; Riegl, 2013).

The relocation of Braga's District Archive is the pretext to discuss the adequacy of this specific program to different qualities that characterize buildings with historic value from different periods. This paper reflects on how the former and present Braga's Archive host buildings, even when not initially designed for this program needs, can be adapted to different use and function. This allows to keep a continuous use of these buildings, still preserving its identity and constitute a valuable contribution for the

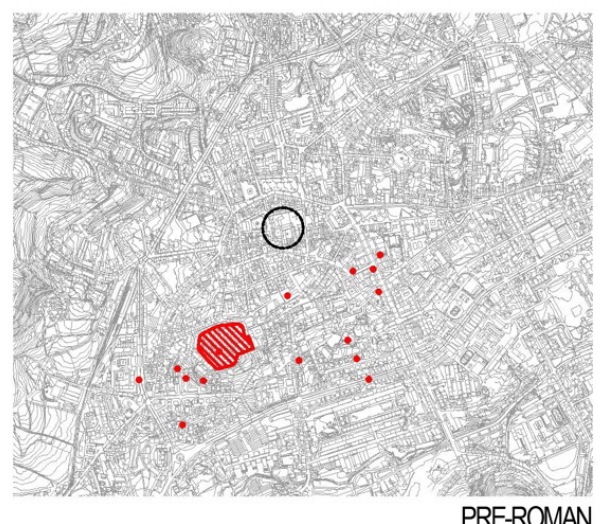

PRE-ROMAN

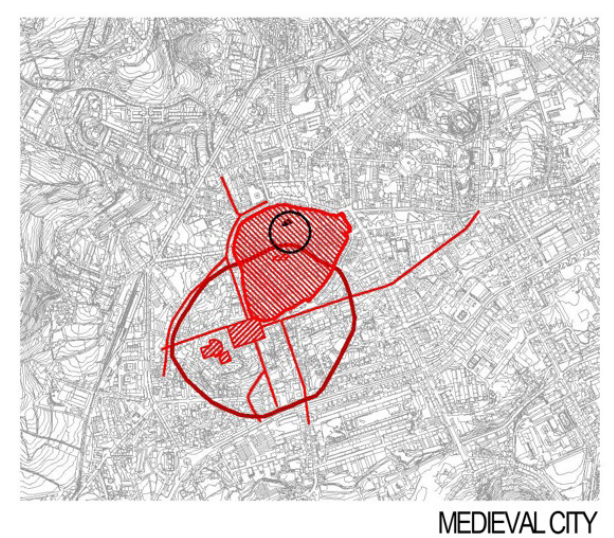

diversity in the city, as adopted by ICOMOS (2011) on The Valletta Principles for the Safeguarding and Management of Historic Cities, Towns and Urban Areas: "Historic towns and urban areas, as living organisms, are subject to continual change. These changes affect all the elements of the town (natural, human, tangible and intangible). Change, when appropriately managed, can be an opportunity to improve the quality of historic towns and urban areas on the basis of their historical characteristics."

\section{Archbishops' Palace}

The Archbishop's Palace, in Largo do Paço, is an example of a flexible structure which has embraced various uses and functions from the XIVth century until today (Figure 1). As a result, the building corresponds to a big volumetric instability of continuous subtractions and addictions (Feio, 1956; Anásiota \& Nunes, 1980; Ribeiro, 2011). This architectural ensemble is located in a central position within the medieval walled city, adjacent to Braga's Cathedral and the City Council (Figure 2) and defines a neighbourhood in which Dr. Justino Cruz, Eça de Queirós, Souto and Misericórdia streets are included (AAVV, 1989). Its initial conformation occurred during the enlargement of the high medieval walls of Braga North, arising with the
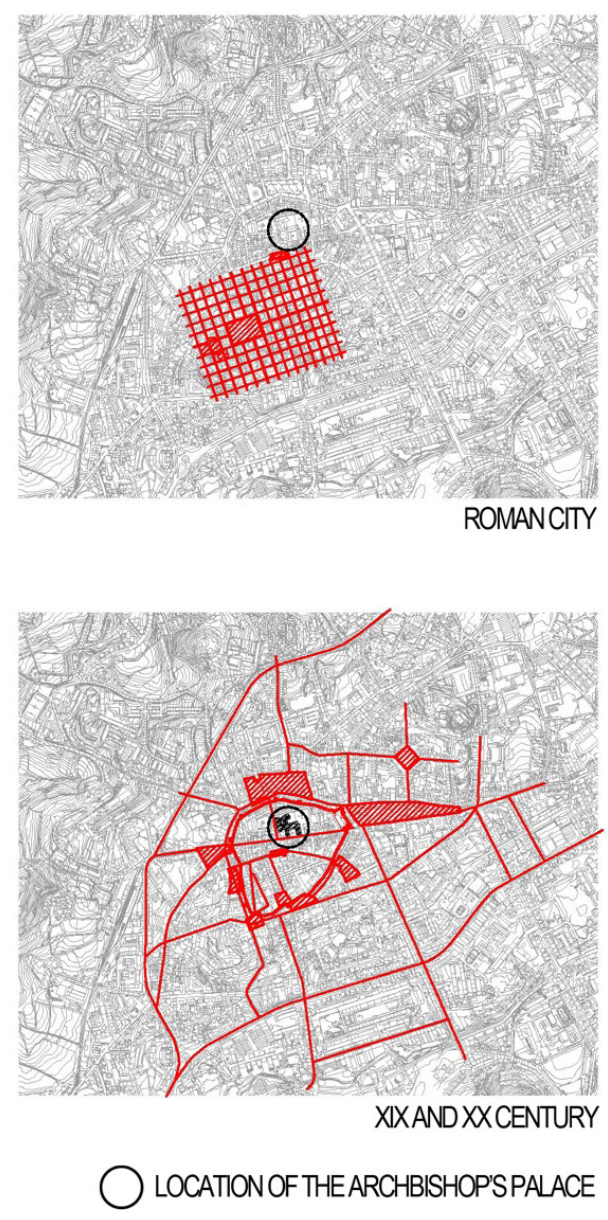

Figure 1. Evolution of Braga 
necessity of providing the archbishops with a residence. There is no precise date for the construction of the first section, but the presence of the Archbishop D. Gonçalo Pereira's Arms, in the building's oldest wing, suggests that it occurred during his reign (between 1326 and 1348).

This building, a sensitive element of urban construction, was absorbed by the different desires and powers that over time ruled the city. Although many interventions took place in the third decade of the $\mathrm{XX}^{\text {th }}$ century, by the Portuguese National Monuments Board, it is possible to verify the existence of three major construction periods: the medieval and initial conformation of the complex (Nunes, 1994; Bandeira, 1994, 2000, 2002; Almeida \& Barroco, 2002), presenting a gothic appearance and located on the North-East, facing the garden of Santa Barbara; a modern U-shaped South section built in the XVI, XVII and XVII$\mathrm{I}^{\text {th }}$ centuries, resembling the model of some squares of the Italian Renaissance; and a Baroque section, known as Paço D. José de Bragança built in the mid eighteenth century, believed to have been drawn by André Soares, one of the most important architects of the Baroque and Rococo period in the Minho Region (Figure 3). The uninterrupted occupation, with several volumetric renovations over the years, according to the prevailing stylistic canons, and the imposition of the external spaces for public use, show the importance of this set to the collective experience of the city. The constructed complex not only projects the inhabitant scale, but with the cathedral, form a structural axis of the medieval city and an expression of a territory (Portas, 2005; Ribeiro \& Melo, 2012).

Presently, the complex comprises a program that includes uses of great cultural and public relevance such as Braga's Public Library, Braga's District Archive and the Rectorate and some services of the University of Minho (Figure 4).

Currently, there is no strong porosity between this representative space and the city's inhabitants. The main reason is not so much its program, but the way it communicates, associated with a degradation of the same spaces.

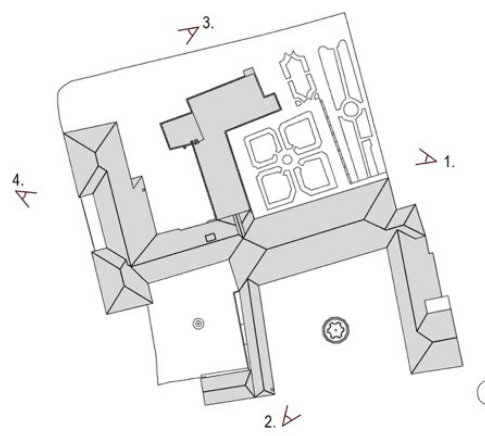

None of the space uses correspond to the initial purpose of the complex, which, besides confirming its flexibility, causes a threat to its preservation and conservation due to the constant adaptations and adjustments, rarely being properly integrated with the pre-existence.

It is known that current technological and infrastructural requirements, including HVAC equipment, electric and electronic wiring, lighting and other management systems, highly impact architectural design and represents a competitor for the little available space; these devices require certain flexibility and spatial freedom, usually not found within most heritage building areas, or not compatible with the preservation of its integrity, which is something that an urban object with this historical and architectonic value requires.
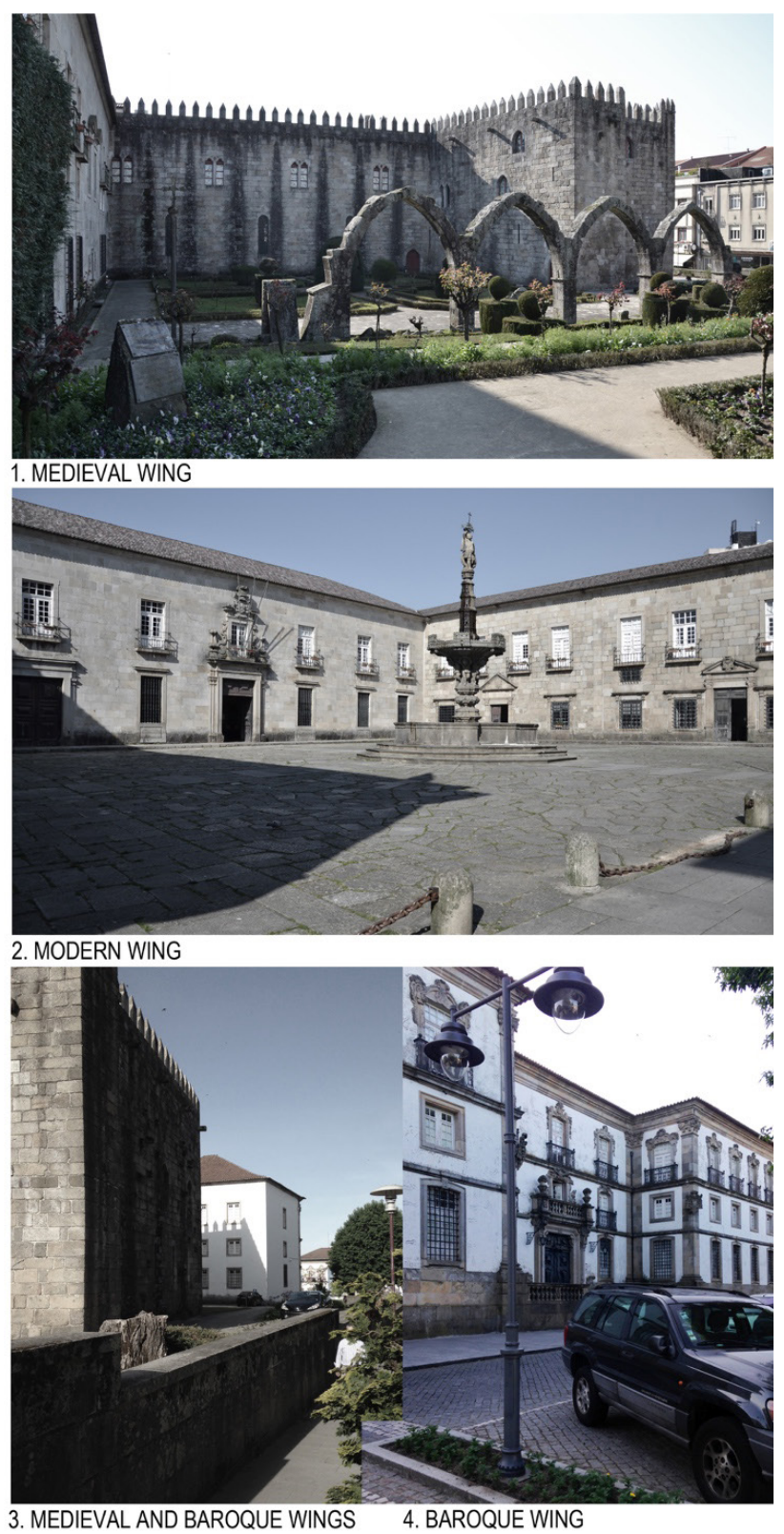

Figure 2. Archbishop's Palace 


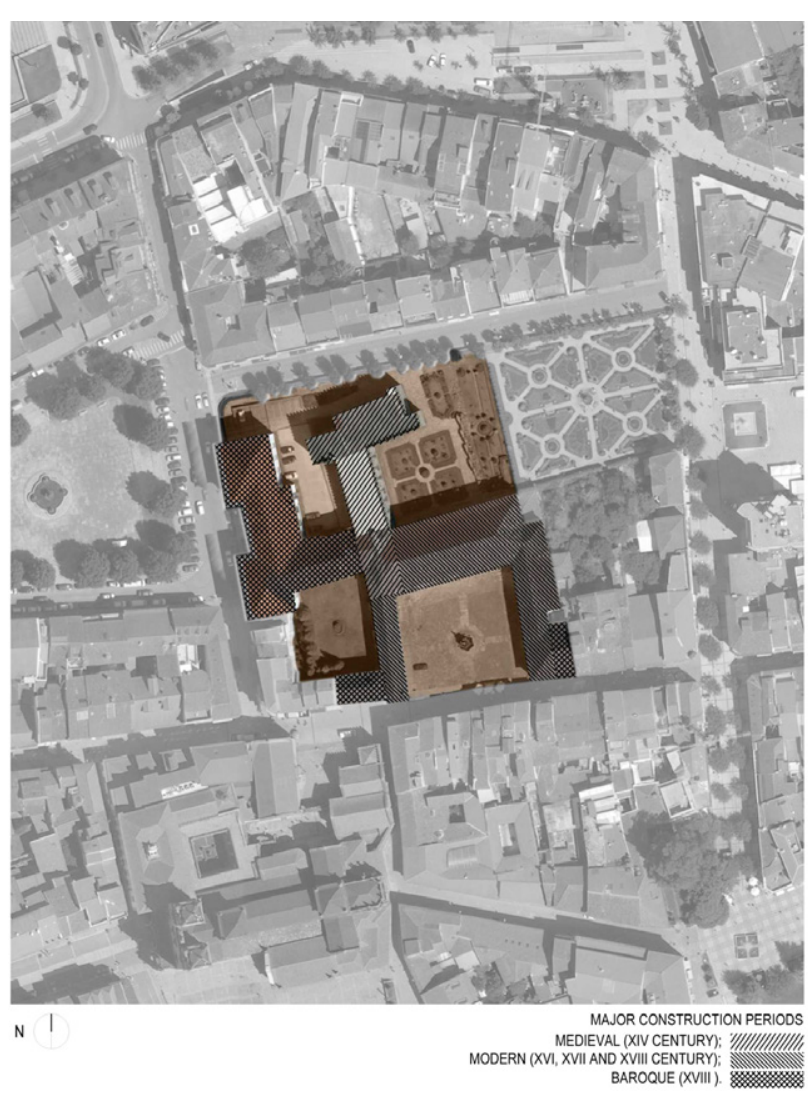

Figure 3. Archbishop's Palace chronology

\subsection{Archbishop's palace Program distribution}

The distribution of the previously described program aimed to respect the different construction periods. However, different spatial and expansion needs over time, especially with the constant increase of the document collection of the Library and Archive, led to disrespecting these limits and to the loss of space clarity.

The Rectorate and some services of the University of Minho occupy today the modern volume. The main entrance lobby, the noble hall and rectorate face Souto Street, while the Human Resources Bureau and the Patrimonial and Financial Services of the University of Minho are in the South-East aisle. The library is located in the Baroque volume, although some of its collection is also in the South-West aisle of the Modern Section, in the room known as Rodrigo Moura-Telles's Gallery.

\subsection{Present location of the Archive}

The Archive represents the buildings biggest challenge due to the dispersion of its program in the Archbishop's Palace. Its public entrance is the same as that of the library, in the Baroque volume, but the rest of the program is fragmented throughout the Medieval and Modern bodies and between some spaces belonging to the Library. This causes multiple misunderstandings that impairs the normal functioning of the Archive: constantly crossing paths with varying degrees of privacy and functions violation; spaces
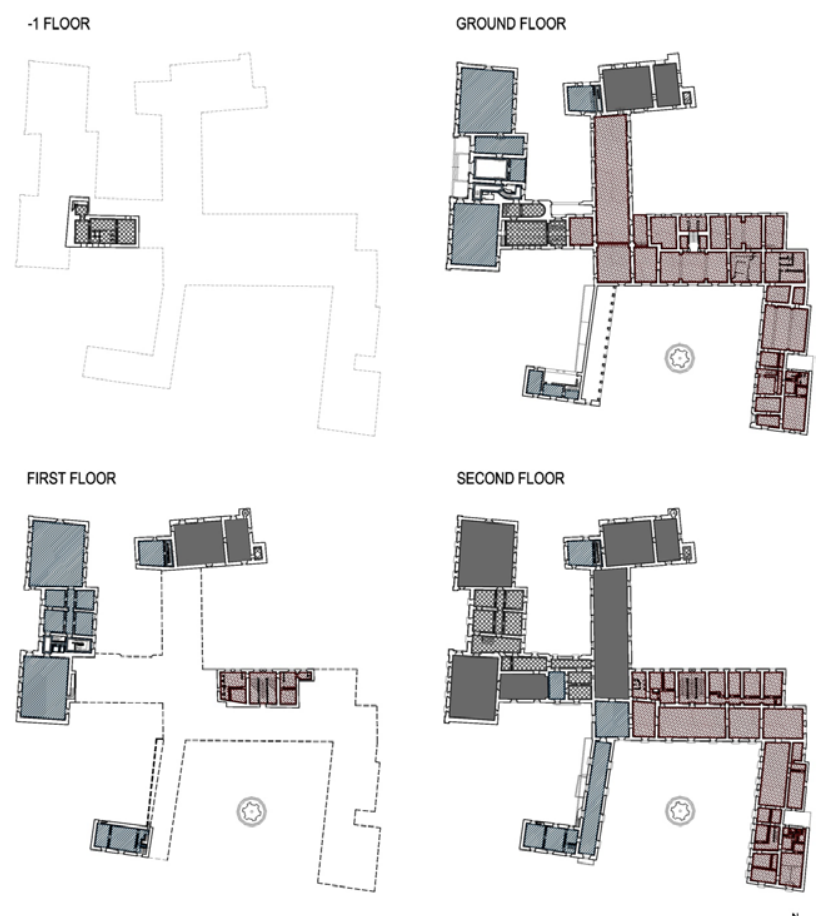

SECOND FLOOR

ALLOATION OF SPACES

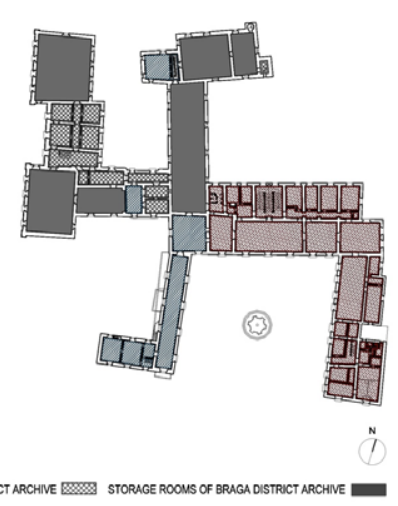

Figure 4. Allocation of spaces

without functional clarity; difficulty in differentiating entities, especially between the Library and the Archive, apart from many others constraints (Figure 5).

In addition, some physical problems that dramatize all these previous issues should also be noted: the high overload that the slabs must support, given that they were not designed and calculated for such function, and the poor air quality and an inadequate, if non-existent, environmental control in almost every space. This last topic is especially severe and cannot be considered as acceptable for an Archive that lodges a large amount of important and sensitive documents, given their acknowledged historical significance (Figure 6).

After this first analysis, it was concluded that the complex is not capable of accommodating these multiple uses without impairing its functionality. Its correct and proper functioning was found to be compromised and that the adequate preservation of the collection is the ultimate reason for the existence of the Archive. Therefore, as an initial strategy for the redevelopment of the Architectural Complex of the Archbishop's Palace, it was imperative and essential that the Archive would find a new space that would ensure the full operation and safeguard of actual and future documents.

The concern regarding the physical preservation of the documentation relegates to second plan two important principles for a full and conscious operation of an Archive: the interpretation and restoration of all the 


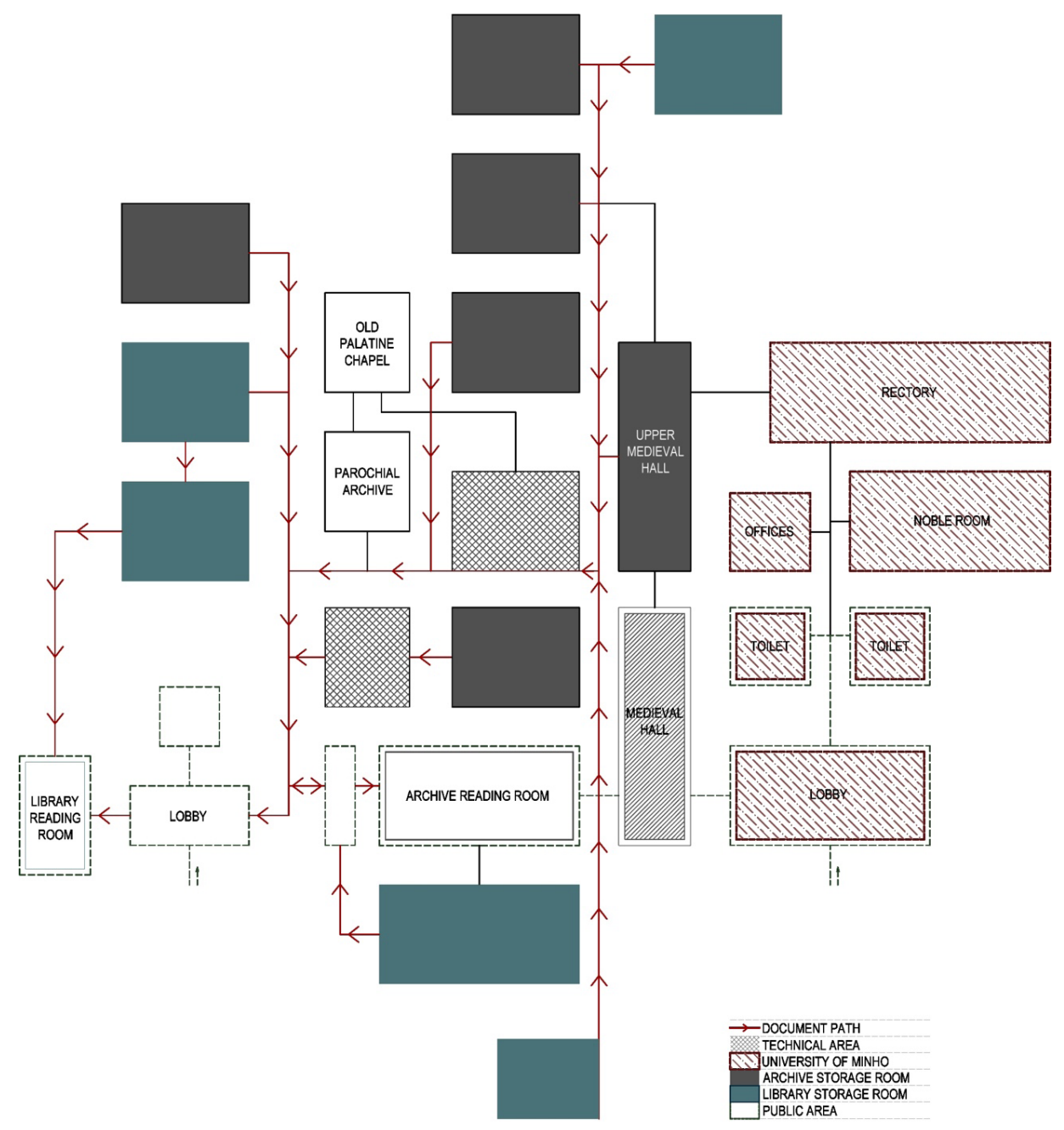

Figure 5. Existent spatial organization
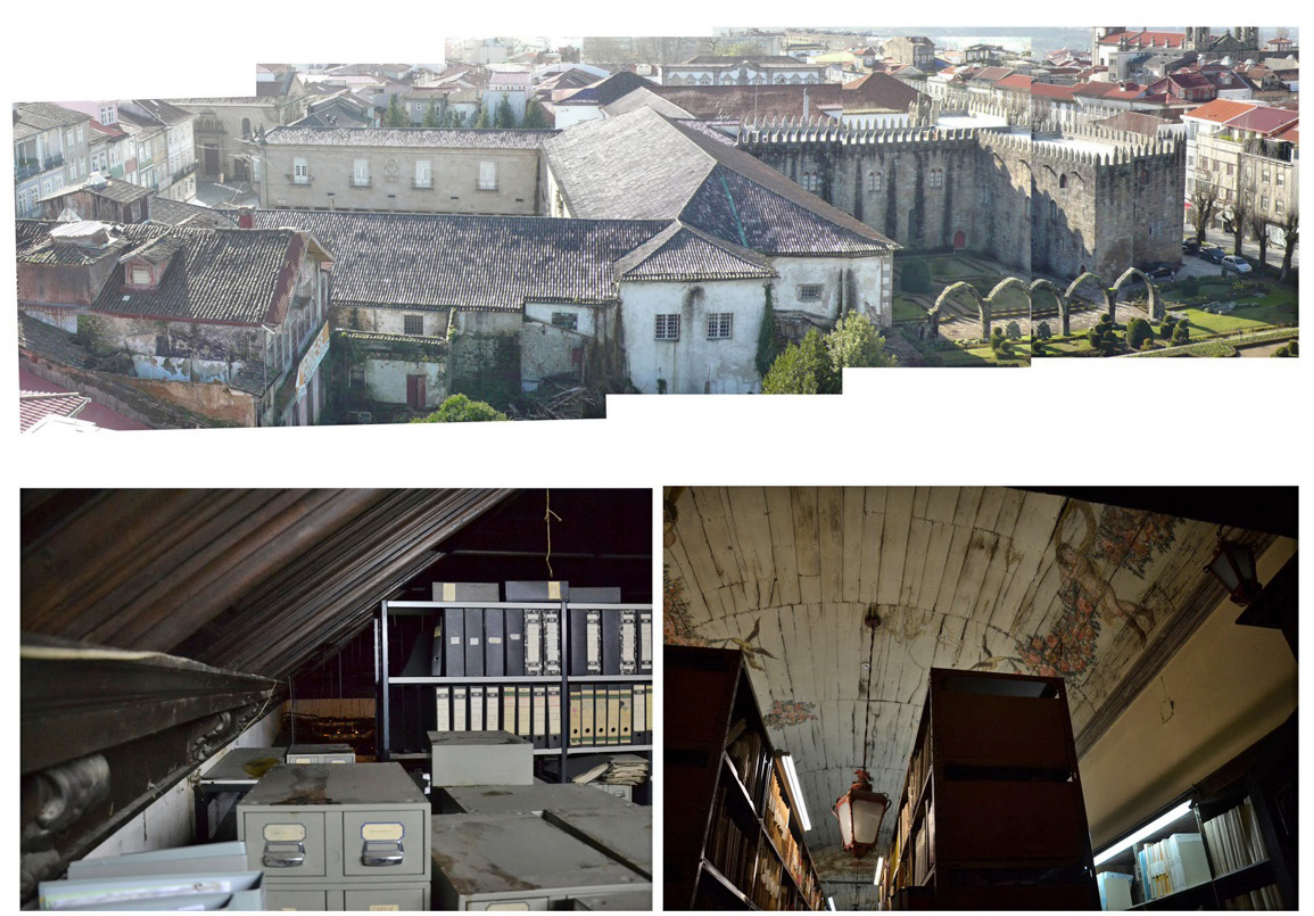

Figure 6. Current state of the Largo do Paço building 
documentation and, the communication of the knowledge produced. It is understood that this advanced binomial, transparency/opacity, entails an evident difficulty and represents one of the major challenges that the contemporary archivist has to face.

\subsection{The Braga's District Archive}

The foundation of Braga's District Archive occurred in 1917, as a result of a decentralization Act, proposed in 1911 by the Law of Separation, as a consequence of the establishment of the Portuguese Republic in 1910. At that time, several District Archives occupied pre-existing buildings, often conventual or monastic, largely abandoned after the extinction of monastic houses and all religious orders in 1834 (Sousa, 2005; Vasconcelos, 2008).

Braga's District Archive began at Congregados's Convent but, since 1937, it has been part of this complex. Today, it is considered the second most important national collection, after the Torre do Tombo National Archive, in Lisbon, due to the high historical value of documents such as the "Liber Fidei", one of the most important medieval cartulary, the Map of streets of Braga, from 1750, and especially the oldest document signed by Afonso Henriques (from 1128), the first King of Portugal.

\subsection{Abade Loureira street}

The new location chosen for the Archive is a pre-existing building, respecting the logic of birth and journey of the collection itself, the reuse of buildings already consoli- dated in the city's fabric (Figure 7). The site is located in Abade Loureira Street, North from the preceding building and adjacent to Braga's Municipal Market. The choice of this location embodies the University's philosophy - the desire to expand into a wider urban context, beyond the Campus walls. It aims to set a paradigm that focuses on the subject of revitalizing urban areas that have lost contact with the urban fabric of historic significance they were once a part of (Pietrogrande et al., 2017), an attitude towards both site and heritage. The University shows, through this proposal, its scope of action regarding the city and its requalification by creating new poles of interest that enable the revival of contexts with its proximity.

The future installations of the Archive foresee to occupy two buildings, corresponding to two separate lots, with a total area of 1298 , being $155.9 \mathrm{~m}^{2}$ impervious areas. The gross floor area is $1567.8 \mathrm{~m}^{2}$ and the useful area is $1275.5 \mathrm{~m}^{2}$.

Its implementation is shaped according to the topography of the site, conditioned by the strong slope of the Abade Loureira Street, around 5\% to 6\%. It must be referred, as an indicative measure, that the difference in elevation between the North and South entrance of the existing building is about $3 \mathrm{~m}$.

The larger building develops along the Abade Loureira Street (the volume that will be maintained) presenting a modernist language from the middle of the $\mathrm{XX}^{\text {th }}$ century, with a singular architectural design, which, associated with environmental and economic savings, aroused the intention of refurbishing the building. The volume
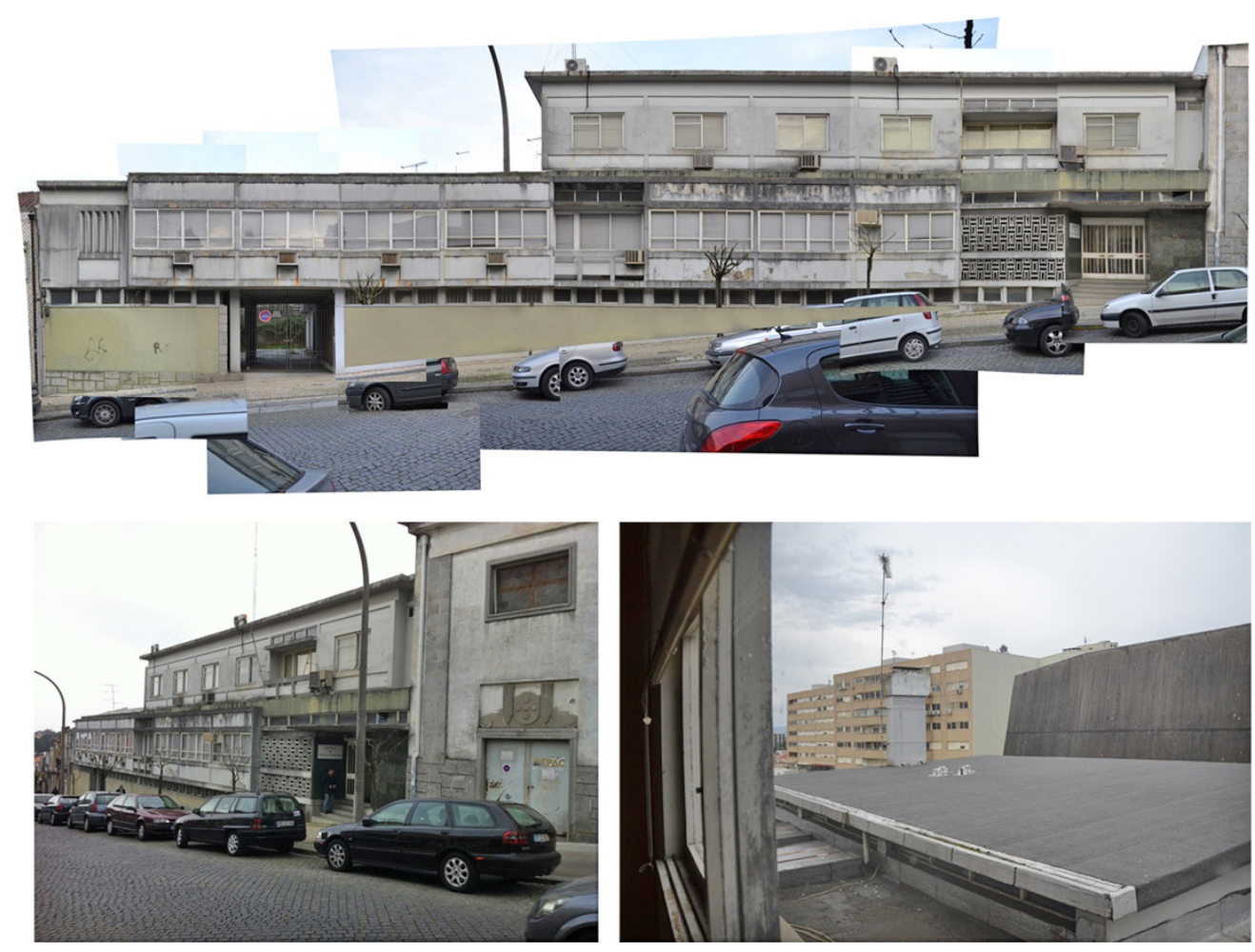

Figure 7. Current state of the Abade Loureira building 


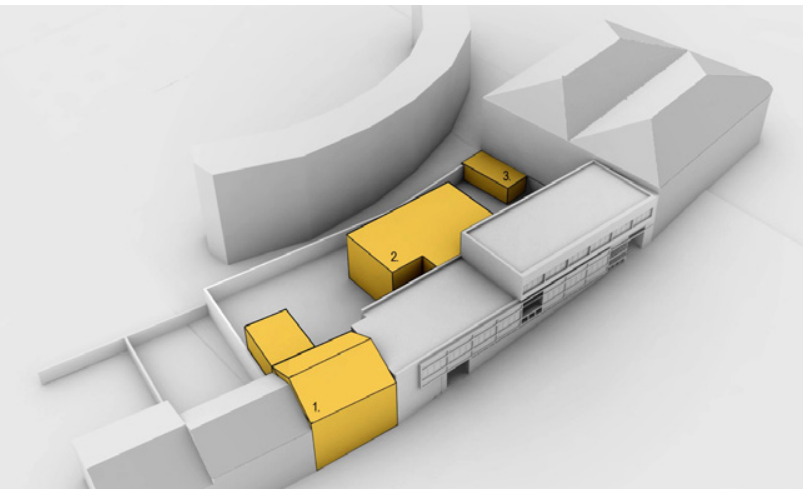

Figure 8. Existing volumes in Abade Loureira Street

is composed of three floors, in which the upper floor, a posteriorly added volume, occupies about half of the area of the other floors. Inside, it is possible to detect an orthogonal structural mesh, where the pillars and beams determine the width of the compartments. The covers are essentially flat, except for a section of the ceiling on the first floor, which has a segmental vault. This building functioned as a Social Canteen but, after 1975, it was transformed into the Psychology and Education School of the University of Minho until 2010. Attached to this volume there is a two-storey building (Figure 8, volume 2), with an East inner connection and a little exterior annex of a single floor (Figure 8, volume 3). On the other plot there is a smaller dwelling of two floors that was the residence of the workers of the Social Canteen. This volume presents less quality or architectural value to justify its maintenance (Figure 8, volume 1).

\section{Program for an archive}

The Preliminary Program for future installation of Braga's District Archive states that "In addition to its organic integration as a University of Minho cultural Unit, Braga's District Archive is an archive of regional character with longterm relationships with entities that produce documents that need to be stored in order to be accessed whenever necessary. By its nature of being a public archive, it articulates with the remaining archives in different levels, particularly with the integrated archives in the Portuguese National Monuments Board and the Municipal Archives of Braga District." (Sousa, 2012)

As explained in the spatial scheme, the organization of space in any archive should consider three distinct chapters - the document, the technical and the user - with infrastructure and specific equipment, establishing the necessary circuits for the activity of the archive. In this context, the document circuit presents itself as a very important part in structuring the program of any archive. The document access must occur in a specific and distinct flux from the employee and user entry in the archive, and should allow for the discharge of documentation sheltered from any kind of adverse and environmental conditions. Hence, the document goes to the technical area comprising a number of treatment rooms, amongst which, maintenance, preservation, restoration, rebinding, packaging, etc. The access circuit of the document ends in the storage volumes, place of its final installation. There should be more than one storage room, with individual areas not exceeding $200 \mathrm{~m}^{2}$, due to fire safety reasons. The storage represents approximately two-thirds of the building's area. Once in the archive, the circuits of the document are basically two, corresponding to two groups of users: technical intervention (internal user) and consultation (external user).

The archive must provide space for user research, by referencing the documents that need to be consulted, although separate from the reading room. It is also necessary and natural for a space of this nature, an administrative area that relates functionally between the public and the technical areas.

\subsection{Design for a new Archive, in a context of cultural significance}

Intervening in built heritage is a broad and complex subject, far from consensual within its own disciplinary area (Foucault, 1988; Lascu, 2004); this article does not intend to go into a deep analysis in the matter.

However, the designing of the Architectural Project for the installation of Braga's District Archive demanded, although in a fairly unconscious way, represents a statement and a position, that should be justified within contexts of great temporal importance. Any action on the territory is a politic statement, embodying its own ideology about both sites and heritage. This process began with the profound study of the building, understanding it critically, which promoting solutions that respected its compositional, symbolic, functional and constructive logics.

Therefore, the design could be established by arguing a tangible and contemporary interpretation of the building, grounding the proposal for its transformation on the qualities of its longue durée, preserving the genius loci - the spirit of the place (Markevičiene, 2012). Simultaneously, the deep knowledge of the pre-existing was the foundation for many of the project's decisions, aiding the design process as well as establishing a hierarchy for the options being made (ICOMOS, 1964, 1987).

Furthermore, the modern heritage of Braga has not yet been studied, in which is included one of its architects, Ramalhete Barbosa, whose objects have been thus far disregarded, despite their remarkable architectonic value. His constructions are part of a network of buildings, which partake in the establishment of a constructive action that reflected the spirit of a specific time.

The difficulty in acknowledging the patrimonial and architectural value in modernist constructions lies, in particularly, with them being so recent in time. Still today, there are some people that advocate the disappearance of modern architecture due to its ephemeral and utilitarian character. However, we defend its preservation and, 
contrary to ancient ruins, its revalorization should stand not only on maintaining its tradition but also on its desire to prevail and its continuous reinterpretation, enriched by the sustainability of its reuse (Cervera, 2011).

Considering the modernist lineage of the building in Abade Loueira, the intervention aims at its heritage requalification and, mainly, in restoring its cultural significance, enlightening the importance of the preservation of its analogous examples, found throughout the city.

During the design process, no doctrine was held a priori regarding its relation with the built mass. However, we find ourselves close to Cesari Brandis's theory, corroborated by Riegl (2013), on the idea of a critical restoration and careful analysis, both sensitive to the pre-existing and intervention area, developing a critical study of the collected material a posteriori. As a strategy for an informed intervention, it will certainly incorporate many of the worries and directives of the multiple charters and documents that established the consensus on good practice when dealing with and handling heritage - these principles support some of the decisions made.

In Varum et al. (2011) and Paiva (2006) can be found some of the structural axis that synthesize, although with some nuances, the decisions that were made from a theoretical and constructive point of view. Example of some of the decisions made include the previous understanding of the building's patrimonial, cultural and technological value, the adaptation of the function to the space and to the building's characteristics, and also the proportional relation that must exist between the depth of an intervention and its accordance to the current regulations for construction demands.

One point where this intervention differs from the presented principles is in the irreversibility of the proposed solution. The new volumes are to be built in concrete and clad with pre-fabricated concrete panels. Although this represents a non-intrusive solution, it is built through techniques, materials and constructive processes similar to the modern movement and, as such, compatible with the building to be intervened. We sought to establish a balanced although challenging dialogue between the parts and authentic in the conception of a true modern building: abstract, economic and essential.

As defended by Brandi and Riegl (Andaloro, 2017), we do not defend the creation of rigid normative and its mechanized application on heritage interventions. We should take each context as non-generalizable (Costa, 2003), with specific data, which despite being processed according to each architect's personal vision, are based on values constantly updated, as it is presented in the 1994 document regarding the Nara Document on Authenticity (UNESCO, 1994):

"All judgements about values attributed to cultural properties as well as the credibility of related information sources may differ from culture to culture, and even within the same culture. It is thus not possible to base judgements of values and authenticity within fixed criteria. On the contrary, the respect due to all cultures requires that heritage properties must be considered and judged within the cultural contexts to which they belong."

The only principles established a priori were to understand the building, known as a material document to be read and transformed, and the will to avert both an historicist and aesthetic proposal, enlightening the characteristics and identities present in the always unique and unrepeatable movement of a body over the (its) territory, interpreted through themes of contemporary urbanity.

Regarding this matter, Távora (1993) stated that "(...) design, plan, draw, should not be translated by the architect as creating shapes empty of meaning, imposed by a wimp of fashion or any other nature. The shapes that will be created should result from a wise balance between their personal vision and the circumstance in which they are involved and as such, should know deeply, so deeply that the knowing and the being merge."

Analysing the preliminary program proposed by the Director of Braga's District Archive, and the building is should be integrated into, it became clear that the building was in need of profound rehabilitation (Paiva, 2016). The program, although very complete and comprehensive, had to be reviewed and readjusted to the buildings spatial and functional adequacy.

Thus, from the conditions imposed by the program which include twenty thousand linear meters of documentation, basic hygiene, security and accessibility guarantees and, above all, due to the stringent technical demands that need to be considered, namely those regarding environmental monitoring, drastically impacted the proposed solution. As is known, it is a finite building, limited to its spatial conditioning and patrimonial worth, therefore, conditioned to modifications and/or eventual expansions. Trying to avoid the profound intervention that would transform the building into a ruin of itself, whipped of authenticity and life, we sought within the deep alterations that needed to be undergone, with the aim of finding a somewhat truth, maintaining a sort of original notion of the building. As such, we proposed to preserve the spatiality of some of its most representative rooms, like the reading room and the access hallway.

In the specific case of the window designs, although those that were later proposed are in aluminium - also respecting the economic factor underlying the project - and incorporating the pre-existing metric and rhythm.

Preserving is, thus, an act of creation (Teixeira, 2013). The intervention, undoubtedly creative - term suggested by the Society for the Protection of Ancient Buildings because of its complexity is projected in the balance of the imperative transformations and with the critical recognition of the building. And prefiguring continuity and ruptures aims to be conscious of its place in time, the ultimate purpose of the true assertion of the modern being. 
Following what was stated in the previous point, regarding the tight fabric of the existing building, and having the structural and spatial organigram drawn, the functional program for the future installations of Braga's District Archive was hierarchical distributed in levels, presenting a simple but effective articulation (Figure 9). In the pre-existing building, the overall program and its most representative public spaces was implemented. The new volumes possess the areas which the main building had no space for. The conference room is located South, enclosing the new building. From the exterior, the volume has a certain dimension, not only due to the necessary balance of scales, but also because it conceals the heavy Heating, Ventilation and Air Conditioning (HVAC) system. Behind it, in the alignment of an adjoining wall oriented to the East, is the needed addition of a new volume for general storage, due to the special conditions that this type of compartment (light, temperature, capacity load, etc.) re- quire, as well as, the significant area required (20000 linear meters) for the documentation (Figure 10), and in order to preserve the main building's integrity.

Separating these two sections is another volume which ensures the horizontal connections between the pre-existing volume and the storage, and will have a complementary program to that of the archive, a multipurpose room for the dissemination and promotion of the archive, as well as to highlight its external image: via exhibitions, conferences and pedagogical activities.

We can roughly synthesize the project's functional areas through different levels that together constitute the Archive's global action:

- On level 0 (Figure 11), are located the technical areas of the complex. In the northern area of this floor is located the direct outdoor access and the generator, as well as all the security installations. A car access allows the entry of documents to a reserved and covered area with access to the building. In the remaining areas, of restricted access, are located the technical zones aimed for maintaining physical documents that may be in need of preventive conservation, restoration, rebinding, scanning, the critical analysis of the documentation and the employee's sanitary facilities;

- On level 1 (Figure 12) are the areas to be used by users, the more public area of the building, where the users can perform their research by referencing the documents wished to be consulted. It will, therefore,

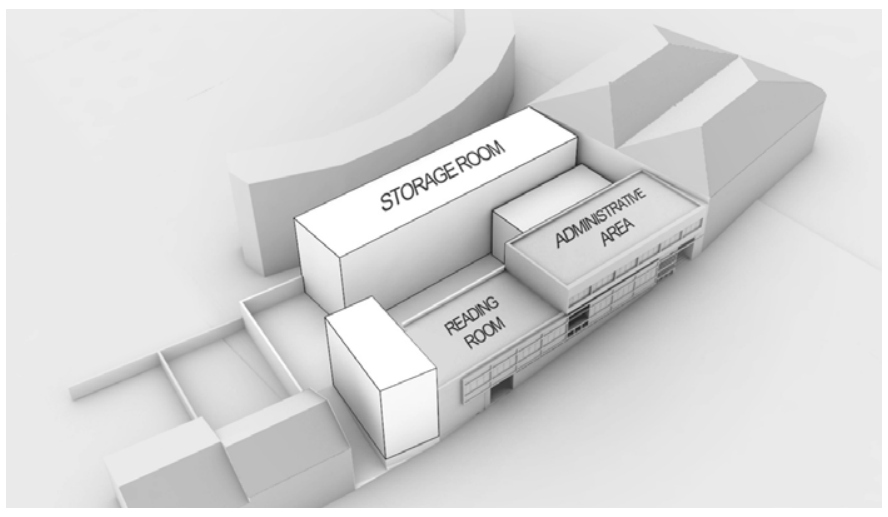

Figure 10. Proposed main program distribution in Abade Loureira

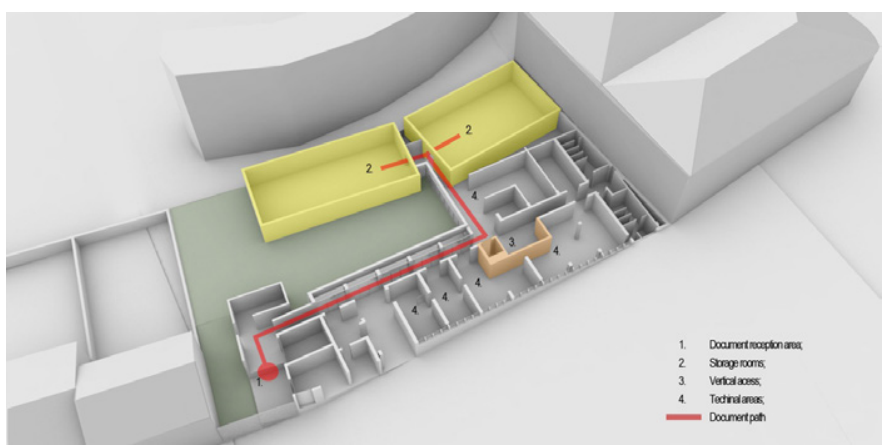

Figure 11. Proposed ground floor in Abade Loureira

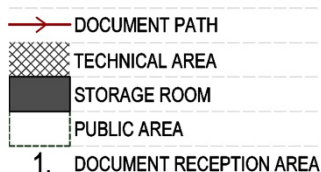

9. Proposed spatial organization 


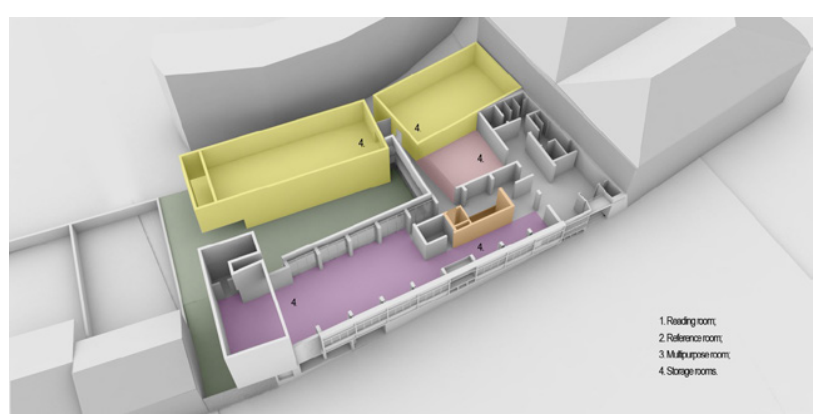

Figure 12. Proposed first floor

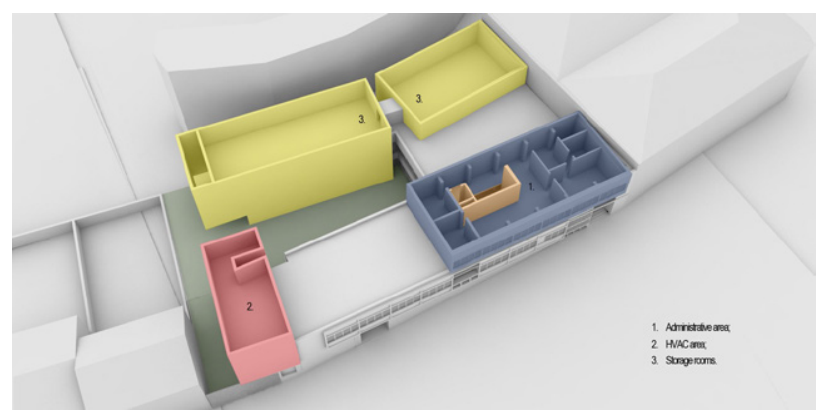

Figure 13. Proposed second floor

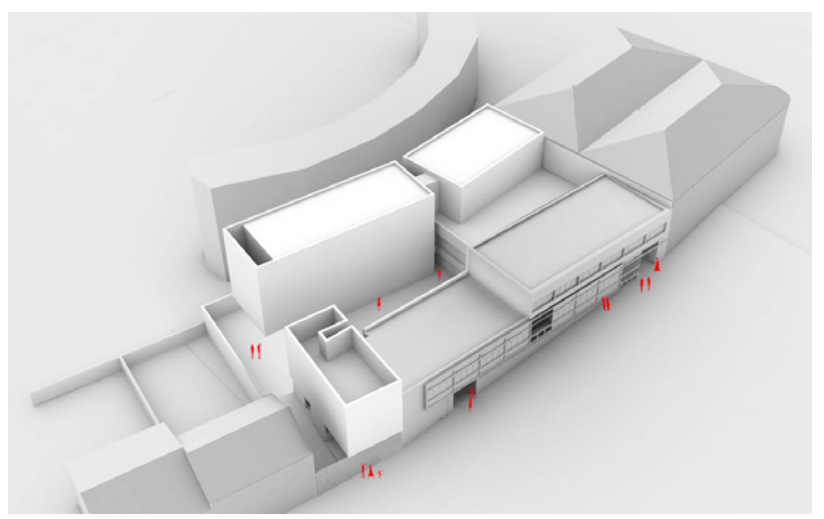

Figure 14. Exterior volume of proposed solution

be composed of a reference room with an office, that also serves the main entrance lobby, a room for groups, a special room for reading, consulting other media supports and the main room for individualized consultation. Complementary to this program is the aforementioned multipurpose room and sanitary facilities that will serve the reading and public spaces.

- Located on the 2nd floor is the administrative area (Figure 13), namely, the secretariat, and the technical offices related to the Director's office.

The existing reinforced concrete structure (beams, columns and slabs) present a characteristic structured grid of last century's fifties decade, having been carefully studied, as already referred, and incorporated while the program was being established in the new draft. For the recovery of the exterior façades, foreseen is the restoration of their original language, and the debugging of all spurious elements placed on the façades in recent years. Figure 14 presents the exterior volume that results from the implementation of the proposed solution.

\section{Comparison between the present and the proposed Archive}

Although conscious of the inherent difficulties facing the introduction of a new use to a pre-existing building, considerable improvements of the proposed solution were observed, when compared to the current location of the Archive, beyond its traditional meaning, in terms of its technical approach, as depicted in Figure 15. Starting with the storage rooms, going from a situation of space overcrowding, with 11000 linear meters of documentation dispersed in multiple buildings with no possibility of its expansion, to a storing of 20000 linear meters of documents
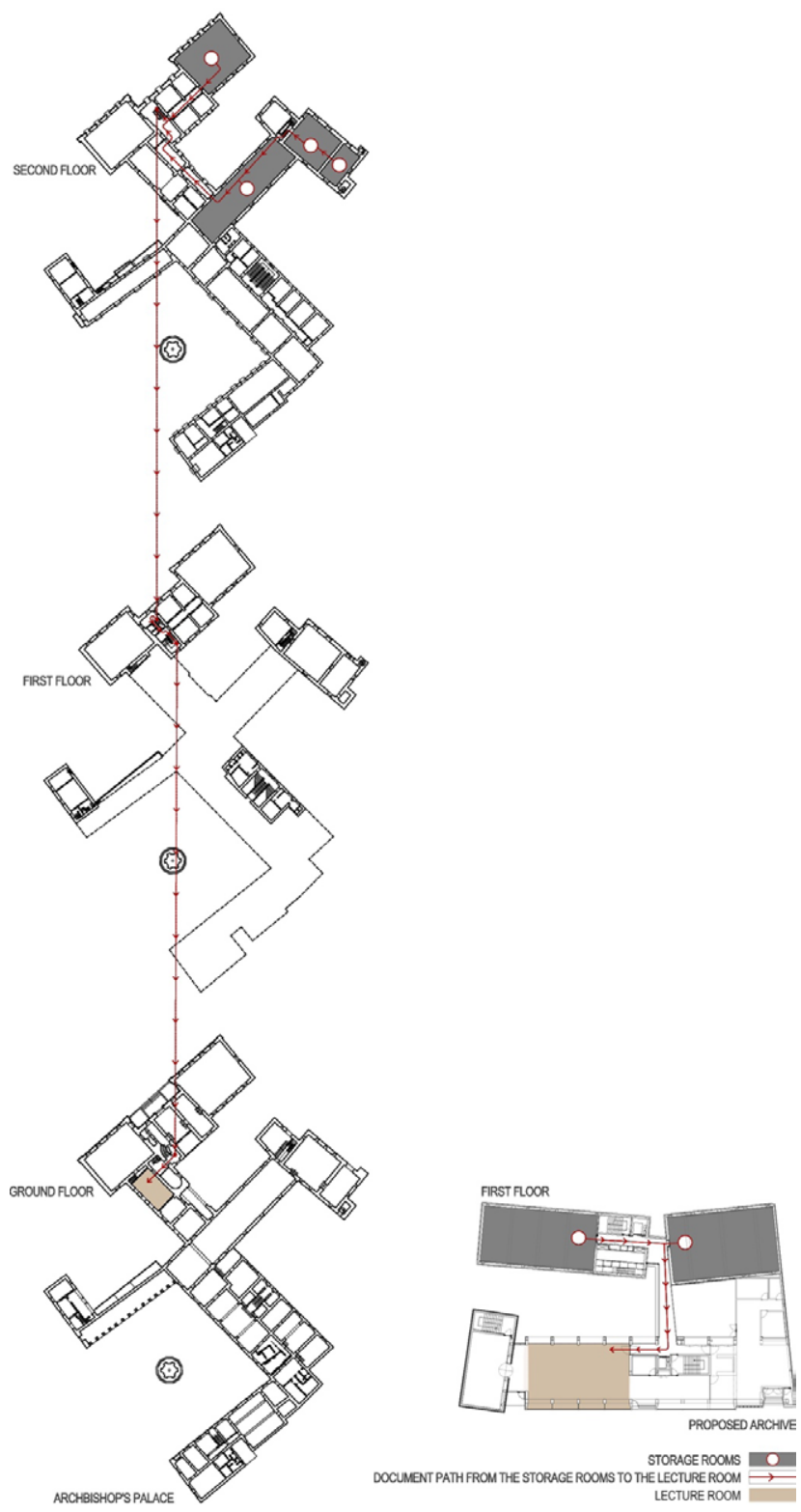

Figure 15. Comparison between the existent and the proposed documents' path 
in a compact building whose circuits facilitate a horizontal distribution between storage rooms with treatment spaces, document access, consultation and reference rooms. In addition, adequate safety and environmental control also being guaranteed.

The areas allocated for the technical work to be done on the documentation arriving at the Archive were increased, ensuring satisfactory working conditions, being organized under a clear linear scheme that links the technical stall with the document storage rooms. Therefore, ensuring the correct conditioning of the documentation that arrive and preventing possible contamination throughout the remaining building.

Since the reading area is one of the essential parts in a functioning archive, it was placed next to the storage building, also allowing important operating enhancements. A previously individualized reading room was attached to the consultation zone, which caused inconvenient noises to those who were consulting the documentation. The total area is $66 \mathrm{~m}^{2}$ and guarantees 24 seats, although the tables are small making the handling of the documents easier. Its orientation is South, which causes a very strong and constant radiation of light during the day. The control of the light is guaranteed through curtains, where then, an almost continuous use of artificial light is required.

The advanced project has an area of individual consultation of $138 \mathrm{~m}^{2}$ and a reference room with $49 \mathrm{~m}^{2}$, being distinct although related areas, in a sequence that connects the entrance hall to the groups consulting room. The individualized consultation area has capacity for 40 seats and for tables roughly twice the size of the existing ones.

Considered from day one, and also as an essential piece of information, the integrated lighting and thermal control systems have been enforced to ensure the accurate technical support for the documentation, without disregarding the spatial quality.

\section{Conclusions}

The relocation of the Braga's District Archive will allow approximately one third of the total space in the Largo do Paço historical complex to be released for thorough refurbishing to take place. This intervention will create the opportunity for its functional reorganization and for one to ponder the occupation of other leftover spaces that may enhance the complex's external image and the services it offers.

The Archive's relocation into a Modernist building, being refurbished and extended for this purpose, will significantly improve the quality of preservation and access to the documents.

The regeneration of both buildings, as pointed out throughout the present pages, is also in line with what Mine (2013) refers to as generic benefits from the adaptive re-use of monuments: economic, by the use of existing structures for new functions in areas of great urban centrality; social, as a building of historical value it presents an ability to trigger the collective memory, giving them an immediate identity character; environmental, by the normal reuse of materials and structural elements and reducing waste from avoiding demolition.

Alves Costa (2003) corroborates this pertinence of the continuous use of the heritage: "conservation prevails when the objects that fascinate and encourage us threaten to collapse, to fall apart, to leave us. And because we want to keep alive the correctness of so many choices, we restore, preserve, reuse, maintain, modify, correct, clean, protect."

It is for fear of loneliness, of being opposed only to ourselves - without the support of those whom in harder conditions have built the sublime - that we cannot and do not want to let this heritage, this legacy, these testimonies, this memory, these traces to disappear.

\section{References}

Andaloro, M. (2017). La teoria del restauro nel Novecento da Riegl a Brandi. Nardini Editore.

AAVV. (1989). Mapa das ruas de Braga (Vols. 1 and 2). Arquivo Distrital de Braga/Universidade do Minho e Companhia IBM Portuguesa.

Almeida, C. A. F., \& Barroca, M. J. (2002). O Gótico, História da Arte em Portugal (Vol. 2). Editorial Presença.

Anásiota, M. M., \& Nunes, H. M. B. (1980). Conjunto Arquitectónico do Largo do Paço: obras de adaptação - 1974-1975. Braga, Universidade do Minho.

Bandeira, M. S. M. (1994). Uma panorâmica seiscentista de Braga. Fórum, 15/16, 25-36. Braga.

Bandeira, M. S. M. (2000). O espaço urbano de Braga em meados do século XVIII. Edições Afrontamento.

Bandeira, M. S. M. (2002). O espaço urbano de Braga - obras públicas, urbanismo e planeamento (1790-1974). Dissertação de Doutoramento, policopiada, 3 volumes. Instituto de Ciências Sociais da Universidade do Minho.

Cervera, J. C. (2011). De lo faisandé a lo efímero: la arquitectura moderna ante el paso del tiempo, Criterios de intervención en el patrimonio arquitectónico del siglo xx. In Conferencia Internacional CAH20thC. Documento de Madrid. Secretaría General Técnica, Ministerio de Cultura.

Costa, A. A. (2003). O Património entre a aposta Arriscada e a confidência nascida da intimidade. Jornal dos Arquitectos, $213,7-13$.

Feio, A. (1956, Outubro 7). Origens da cidade. Destruição de Bracara Augusta. Diário do Minho.

Foucault, M. (1988). Of other spaces: utopias and heterotopias, 1967. In R. Barthes (Ed.), The semiotic challenge (pp. 420426). Hill and Wang.

ICOMOS. (1964). International Charter for the Conservation and Restoration of Monuments and Sites (The Venice Charter 1964). International Council on Monuments and sites.

ICOMOS. (1987). International Charter for the Conservation of Historic Towns and Urban Areas (Washington Charter 1987). International Council on Monuments and sites.

ICOMOS. (2003). The Valletta Principles for the Safeguarding and Management of Historic Cities, Towns and Urban Areas (Valleta Charter 20). International Council on Monuments and sites.

Lascu, L. F. (2004). Built heritage conservation and urban regeneration process in the historical core of Bucharest. Academic Journal, 15(139). 
Markevičiene, J. (2012). The spirit of the place-the problem of (re) creating. Journal of Architecture and Urbanism, 36(1), 73-81. https://doi.org/10.3846/20297955.2012.679789

Medina, A. M. (2011). The fingerprints of the time in the modernist reformed architecture. In Conferencia Internacional CAH20thC. Documento de Madrid. Secretaría General Técnica, Ministerio de Cultura.

Mine, T. Z. (2013). Adaptive re-use of monuments "restoring religious buildings with different uses". Journal of Cultural Heritage, 14, 3 Supplement, S14-S19. https://doi.org/10.1016/j.culher.2012.11.017

Nunes, H. B. (1994). Uma imagem inédita de Braga no Século XVII. Fórum, 15/16, 21-23. Braga.

Paiva, J. (2006). Guia técnico de Reabilitação habitacional, 1. LNEC.

Pietrogrande, E., Dalla Caneva, A., \& Navàs Salvadó, I. (2017). Disused areas and urban regeneration. The historic centre of Vicenza, Italy. Journal of Architecture and Urbanism, 41(1), 60-70. https://doi.org/10.3846/20297955.2017.1296796

Portas, N. (2005). Os tempos das formas, 1. A Cidade Feita e Rarefeita, Universidade do Minho.

Ribeiro, M. C. F. (2011). O antigo Paço Arquiepiscopal de Braga. Colecção Sítios com História, Reitoria da Universidade do Minho.

Ribeiro, M. C. F., \& Melo, A. S. (2012). A materialização dos poderes no espaço como expressão da memória e identidade urbana medieval, Medievalista. Departamento de História da Universidade do Minho.

https://doi.org/10.4000/medievalista.685
Riegl, A. (2013). O culto moderno dos monumentos. Lisboa, Edições 70.

Rodwell, D. (2003). Sustainability and the holistic approach to the conservation of historic cities. Journal of Architectural Conservation, 9(1), 58-73. https://doi.org/10.1080/13556207.2003.10785335

Sousa, A. (2005). 90 años: Los archivos de distrito en Portugal. Tabula, 8, 69-79.

Sousa, A. (2012). Preliminary program for future installation of Braga District Archive. University of Minho, Braga.

Távora, F. (1993). Teoria geral da organização do espaço: arquitetura e urbanismo: a lição das constantes. Porto, FAUP Publicações.

Teixeira, J. (2013). Salvaguarda e valorização do edificado habitacional da cidade histórica: metodologia de intervenção no sistema construtivo da Casa Burguesa do Porto (Tese de Doutoramento). FAUP.

UNESCO. (1994, 1-6 November). The nara document on authenticity. Experts meeting. Convention concerning the protection of the world cultural and natural heritage (WHC-94/ CONF.003/INF.008).

Varum, A. T. A. C. H., Tavares, A., \& Costa, A. (2011). Manual de Reabilitação e Manutenção de Edifícios Guia de intervenção. INOVADOMUS.

Vasconcelos, M. A. J. (2008). O Arquivo e a cidade. Páginas da história bracarense, Braga, Arquivo Distrital. 